\title{
The Effect of Big Five Personality Types and Family Support for Career Decision Making of the Students of Man 2 Cianjur
}

\author{
Windy Tri Wahyuni ${ }^{1}$, Achmad Syahid ${ }^{2}$ \\ Facultyof Psychology, UIN Syarif Hidayatullah Jakarta \\ windytw2@gmail.com¹,achmad_syahid@uinjkt.ac.id²
}

\begin{abstract}
The research is to examine the influence of big five personality types and family support on the career decision making of MAN 2 Cianjur students. The population of this study was 320 students of MAN 2 Cianjur. The sample of this study were 210 people selected by convenience sampling technique The author uses Assessment of Career Decision Making, Big Five Inventory (BFI) and Family Support as a measuring instrument. Test the validity of measuring instruments using the Confirmatory Factor Analysis (CFA) technique anddata analysis uses multiple regression analysis techniques.The results of this study indicate that there is a significant influence of the big five personality types on rational career decision making and intuitive career decision making, and there is no significant effect of the big five personality type variables and family support on dependent career decision making.
\end{abstract}

Keywords: Career Decision Making, Big Five Personality, Family Support, State Islamic Senior High School (MAN).

\section{Introduction}

Fabio, Palazzeschi, AsulinPeretz \& Gati (2012) mention that eventhough it is not easy, career decision making must be passed by someone in his life. Career decision making is a systematic process in which individuals analyze data that leads to self-expression such as motivation, knowledge, personality and abilities(Widyastuti \& Pratiwi, 2013).Harren (in Mau, 2000 ) is point out that career decision making is also a psychological process that is influenced by experience to anticipate responsibly for oneself with the development of his career capacity.

Stepping on the adolescent phase, is an important task for MAN students to begin actively exploring their interests and talents in order to develop their careers and aspirations appropriately. Because adolescence is the right time to evaluate, make decisions, commit and carve out a place in the world with achievement (Santrock, 2011).

Considering that, students majoring in natural and social sciences MAN 2 Cianjur were given additional skills programs similar to Vocational Schools, such as Network Computer Engineering (TKJ), catering and fashion. Alsoprovided an internship program directly at work. They visited various universities to find out the profile of study programs provided. From interviews with several 12th grade students at MAN 2 Cianjur, it was found that several factors made it difficult for them to choose majors in college because they felt confused in the decision making process of their further study majors. Students change the choice of study majors several times to be addressed, because they are less confident in their choices and lack of confidence in the ability to be able to compete with other registrants. Students are also 
unsure of career considerations after graduation because competition in the workforce is very tight. There are students who claim to choose majors without having further knowledge related to these majors. In addition there are also students who find it difficult in the selection of majors due to doubts about their own potential. This shows the lack of understanding of the career orientation of students and if left unchecked will lead to mistakes in majors and impact on the lecture process.

Research Fadilla, Sinring and Aryani (2015) regarding career decisions making of SMAN (State Senior High School)3 students in Makassar; it is found that around $70 \%$ of students have not been able to make career decisions and are still confused about making the right choice of majors or study programs, as well as choosing the field of work to be pursued. From the results of a survey to counseling teachers and direct observations at SMA Negeri 3 Makassar many students often come to meet the counseling teacher for consultations on various matters relating to the future of their careers, both those related to study programs at tertiary institutions, as well as the type of work in fit with and accordance with their talents and abilities.

According to Pervin, Cervone and John (2010) alsoFabio, Palazzeschi and Baron (2012), personality is one of the factors that influence career decision making; that is, the characteristics of a person which causes the consistency of feelings, thoughts and behavior. Research Pejak and Kosir (2007) found that personality influences the difficulty of career decision making. Individuals who have high scores on extraversion, conscientiousness, openness and stable emotions will be more competent in making decisions and experiencing fewer decision-making difficulties.

Besides personality, another variable that influences career decision making is family support.According to Johnson and Johnson (in Widyastuti and Pratiwi, 2013) social support comes from significant others is very important to individuals who need help. This research emphasizes the family's social support which is considered as the most important person in student life.High family support will increase one's stability in decision making (Widyastuti and Pratiwi, 2013). The family is a gathering place for people who are ready to provide emotional, social, economic support to individuals at all times (Kaur, Kaur, and Venkateashan, 2015).

According to Dolan, Canavan and Pinkerton (2006), an assistance such as guidance and support provided by significant others to family members in need is expected to provide clear direction. The support given by significant others is warm, understanding, sincere and it is the best form of service. Students with high family support will have positive thoughts about difficult situations compared to students who have low levels of support. In addition it was also mentioned that students who believe that parents are always there to help, will be better able to cope with potentially stressful events more effectively.

\section{Theoritical Frameworks}

\subsection{Career Decision Making}

Harren (1976) argues that career decision making is a psychological process in organizing information, considers various alternatives and makes a commitment to an action taken.Individuals search for information and pay attention to the various types of careers and jobs available, after which individuals make decisions and a commitment to the career and work they have chosen.According to Harren there are three groups of career decision making: 
a) Rational, which is marked by the individual making some logical considerations and careful planning before making a decision regarding his career.

b) Intuitive, which is characterized by individuals seeking information and making career decisions based on feelings and not paying attention to logical considerations.

c) Dependent, which is marked by the individual does not care much about his career because in making decisions more dependent on others.

Harren (1979) also point out that effective career decision making is based on logical thinking and problem approaches as well as careful planning.

\subsection{Big Five Personality Types}

Lee and Ashton (1966) and Pervin, Cervone and John (2010)referring to personality is a characteristic of a person which causes the consistency of feelings, thoughts and behavior. WhilePervin and Cervone (2011) personality is a psychological quality that contributes to an individual's enduring and special patterns of feelings, thought patterns and behavior.Mc.Crae and Costa (1987)define personality as a systematic description of traits. Mc. Crae dan Costamentioned that personality consists of five types:

a) Neuroticism, that is, personality types that are characterized by anxiety, temperament, selfpity, emotionality and vulnerability to stress-related disorders.

b) Extraversion, that is the type of personality that is characterized by loving, cheerful, happy to talk, happy to gather and fun.

c) Openness to experience,namely the personality type that is characterized by imaginative, creative, innovative, curious and has a high curiosity.

d) Agreeableness, hat is, personality types characterized by trustworthy, generous, succumbing, receptive, and have good behavior.

e) Conscientiousness, that is, personality types that are characterized by regularity, controlled, organized, ambitious, focused on achieving and having self-discipline.

\subsection{Family Support}

The family is the first environment for individuals, the family also plays a role in providing support for family members because it affects the life of an individual (Istifarani, 2016). The optimal pattern of family interaction will be useful for understanding what are the factors that influence children in their development, both biologically and psychologically (Guralnick, 2006). Family support is an act of assistance given to family members who need to get direction for future careers. The support provided is warm and the best service (Dolan, et. al., 2006).

Dolan et al. (2006) dividing family support into four dimensions:

a) Concrete support, which isan actions or assistance provided in real terms to the family or others, in this case real assistance is really needed in a family.

b) Emotional support, which is an action in the form of empathy and is there when needed by the family. Providing emotional support must be careful because it is a bit sensitive and emotional support is needed.

c) Appreciation support, which is an action given to assess and inform the family about positive things. Providing mutual assistance and appreciation will build a harmonious family.

d) Support for advice, which is the action given in the form of advice or input to the family when needed, in this case the advice is very helpful to convince the family's opinion. 


\section{Method}

The population of this study is students of grade XII MAN 2 Cianjur, totaling 320 students. The research sample of 210 people were chosen by the formula Isaac and Michael (in Merterns and McLaunglin, 2004). The sampling technique uses a non probability sampling technique, in which in selecting the sample the author does not provide equal opportunities to all members of the population, but based on the availability of samples or at the time of data collection, using convenience sampling techniques.

\subsection{Statistical Analysis}

This study was designed to examine the significance of the effect of the big five personality types and family supports as an independent variables on the career decision making of the student of MAN 2 Cianjur as a dependent variable using multiple linear regression analysis using IBM SPSS Statistics 20 software.

\subsection{Statistical Analysis}

\section{a) Career Decision Making}

Career decision making is measured using Harren's instrument (1979) on Assessment of Career Decision Making. This instrument consists of 48 items and is measured by 4 Likert model scale ranges i.e. 1 to strongly disagree - 4 to strongly agree.

\section{b) Big five Personality Types}

Big five personality types are measured using the Big Five Inventory (BFI) measuring instrument from John (1991). This measurement consists of 44 items and is measured by 4 Likert model scale ranges ie 1 to strongly disagree - 4 to strongly agree.

\section{c) Family Support}

Family support is measured by Family Support proposed by Dolan et al. (2006). This instrument device originally consisted of 66 items, but in this study it was adapted to only use 24 items. This instrument is measured with 4 ranges of Likert scale models namely 1 to strongly disagree - 4 to strongly agree.

\section{Results and Discussion}

\subsection{Results of Hypothesis of Rational Career Decision Making Regression Analysis}

Table 1. R Square

\begin{tabular}{cccccc}
\hline Model & R & R Square & Adjusted R Square & Std. Error of the Estimate & Sig. F Change \\
\hline 1 & $.622 \mathrm{a}$ & .387 & .360 & 6.97008 & .000 \\
\hline
\end{tabular}

Predictors: (Constant), Suggestion Support, Neuroticism, Conscientiousness, Agreeablenes, Extraversion, Concrete Support, Opennes, Emotional Support, Award Suppor.t 
Table 1 shows that the R-Square is 0.387 or $38.7 \%$. That is, the proportion of the rational career decision variable variance is explained by the big five personality types variables (extraversion, agreeableness, conscientiousness, neuroticism, opennes) and family support (concrete support, emotional support, appreciation support, and suggestion support) in this study by $38,7 \%$, while the remaining $61.3 \%$ is influenced by other variables outside this study.

\subsection{Anova Effect of Independent Variables on Rational Career Decision Making}

Table 2. Anova

\begin{tabular}{ccccccc}
\multicolumn{8}{c}{} & \multicolumn{7}{c}{ ANOVA $^{\mathbf{a}}$} \\
\hline \multirow{4}{*}{1} & Model & Sum of Squares & Df & Mean Square & F & Sig. \\
\hline & Regression & 6142.450 & 9 & 682.494 & 14.048 & $.000^{\mathrm{b}}$ \\
& Residual & 9716.409 & 200 & 48.582 & & \\
\hline & Total & 15858.859 & 209 & & & \\
\hline
\end{tabular}

Based on the F test results in Table 2, it can be seen that the p value (Sig.) In the rightmost column is $p=0,000$ with a $p$ value $<0.05$. While it is known that the requirements for fulfilling the Sig. is $<0.05$, then the null hypothesis which states that "there is no significant effect of the big five personality types variabels (extraversion, agreeableness, conscientiousness, neuroticism, openness) and family support (concrete support, emotional support, appreciation support and advice support) on behavior rational career decision making", rejected. The opposite means "there is a significant influence of the big five personality types (extraversion, agreeableness, conscientiousness, neuroticism, openness) and family support (concrete support, emotional support, appreciation support and advice support) on rational career decision making". The magnitude of the regression coefficients of each independent variables on rational career decision making can be seen in Table 3 .

Tabel 3. Regression Coefficient

\begin{tabular}{ccc}
\hline Model & B & Sig \\
\hline Extraversion & .185 & $.004^{*}$ \\
Agreeableness & .089 & .141 \\
Conscientiousness & .220 & $.001^{*}$ \\
Neurotism & .128 & .052 \\
Openness & .192 & $.003^{*}$ \\
Concrete Support & .117 & .119 \\
Emotional Supposrt & -.122 & .129 \\
Award Support & .130 & .179 \\
Suggestion Support & .085 & .348 \\
\hline
\end{tabular}

Based on the regression coefficients in Table 3, the regression equation is as follows: (* significant) rational career decision making $-1.174+0.185$ (extraversion) $*+0.089$ (agreeableness) +0.220 (conscientiousness) $*+0.128$ (neuroticism) +0.192 (openness) $*+$ 0.117 (concrete support) +-0.122 (emotional support) +0.130 (award support) +0.85 (suggestion support) + e. From the regression equation, it can be seen that there are three variables with significant regression coefficient values, namely; (1) extraversion, (2) conscientiousness and (3) openness. 


\subsection{Proportionof Variants}

Table 4. The Contribution of Each Independent Variables Variant

\begin{tabular}{cccccccc}
\hline & & & \multicolumn{5}{c}{ Change Statistics } \\
\cline { 4 - 8 } Model & $\mathrm{R}$ & R Square & $\begin{array}{c}\text { R Square } \\
\text { Change }\end{array}$ & F Change & $\mathrm{df1}$ & $\mathrm{df2}$ & Sig F Change \\
1 & $.337^{\mathrm{a}}$ & .114 & .114 & 26.701 & 1 & 208 & .000 \\
2 & $.433^{\mathrm{b}}$ & .187 & .074 & 18.722 & 1 & 207 & .000 \\
3 & $.543^{\mathrm{c}}$ & .295 & .108 & 31.563 & 1 & 206 & .000 \\
4 & $.559^{\mathrm{d}}$ & .313 & .017 & 5.166 & 1 & 205 & .024 \\
5 & $.593^{\mathrm{e}}$ & .352 & .039 & 12.380 & 1 & 204 & .001 \\
6 & $.611^{\mathrm{f}}$ & .373 & .021 & 6.750 & 1 & 203 & .010 \\
7 & $.613^{\mathrm{g}}$ & .373 & .000 & .064 & 1 & 202 & .800 \\
8 & $.620^{\mathrm{h}}$ & .385 & .012 & 3.806 & 1 & 201 & .052 \\
9 & $.622^{\mathrm{i}}$ & .387 & .003 & .883 & 1 & 200 & .348 \\
\hline
\end{tabular}

Based on the data in Table 4 it can be seen that:

a) The variable extraversion contributes $11.4 \%$ to the variance of rational career decision making.

b) The agreeableness variable contributed $7.4 \%$ to the rational career decision making variance.

c) Conscientiousness variable contributed $10.8 \%$ to the variance of rational career decision making.

d) The neuroticism variable contributes $1.7 \%$ to the variance of rational career decision making.

e) The openness variable contributes $3.9 \%$ to the variance of rational career decision making.

f) Concrete support variables contributed $2.1 \%$ to the variance of rational career decision making.

g) The emotional support variable contributed $0 \%$ to the variance of rational career decision making.

h) The award support variable contributes $1.2 \%$ to the variance in career decision making.

i) The advice support variable contributes $0.3 \%$ to the variance in career decision making.

\subsection{The Hypothesis Results of Intuitive Career Decision Making Regression analysis}

Table 5. R Square

\begin{tabular}{cccccc}
\hline Model & R & R Square & Adjusted R Square & Std. Error of the Estimate & Sig. F Change \\
\hline 1 & $.439^{\mathrm{a}}$ & .193 & .156 & 8.21312 & .000 \\
\hline
\end{tabular}

In Table 5 it can be seen that the R-Square is 0.193 or $19.3 \%$. That is, the proportion of variants to the variables of intuitive career decision making is explained by the personality variables of the big five (extraversion, agreeableness, conscientiousness, neuroticism, opennes) and family support (concrete support, emotional support, appreciation support, and 
suggestion support) in this study of $19,3 \%$, while the remaining $80.7 \%$ is influenced by other variables outside this study.

\subsection{Anova on Influence of Independent Variables on Intuitive Career Decision Making}

\begin{tabular}{ccccccc}
\multicolumn{8}{c}{$\begin{array}{c}\text { Table 6. Anova } \\
\text { ANOVA }\end{array}$} \\
\hline & Model & Sum of Squares & df & Mean Square & F & Sig. \\
\hline \multirow{2}{*}{1} & Regression & 3219.585 & 9 & 357.732 & 5.303 & $.000^{\text {b }}$ \\
& Residual & 13491.082 & 200 & 67.455 & & \\
& Total & 16710.668 & 209 & & \\
\hline
\end{tabular}

F test results in Table 6, can be seen that the value of $\mathrm{p}$ (Sig.) In the rightmost column is $\mathrm{p}$ $=0,000$ with a value of $p<0.05$. While it is known that the requirements for fulfilling the Sig. is $<0.05$, then the null hypothesis which states that "there is no significant effect of the big five personality types (Extraversion, agreeableness, conscientiousness, neuroticism, opennes) and family support (concrete support, emotional support, appreciation support, and suggestion support) on intuitive career decision making behavior ", rejected. The opposite means "there is a significant influence of the big five personality types (extraversion, agreeableness, conscientiousness, neuroticism, opennes) and family support (concrete support, emotional support, appreciation support, and advice support) towards intuitive career decision making". The magnitude of the regression coefficients of each independent variable on intuitive career decision making can be seen in Table 7.

Table 7. Regression Coefficient

\begin{tabular}{ccc}
\hline Model & B & Sig \\
\hline Extraversion & .189 & $.012^{*}$ \\
Agreeableness & .147 & $.041^{*}$ \\
Conscientiousness & .158 & $.044^{*}$ \\
Neuroticism & -.071 & .360 \\
Openness & .075 & .327 \\
Concrete Support & .133 & .132 \\
Emotional Supoort & -.007 & .943 \\
Award Support & -.076 & .503 \\
Suggestion Support & .017 & .870 \\
\hline
\end{tabular}

Based on the regression coefficients in Table 7, the regression equation is as follows: (* significant) Intuitive career decision making $=21,730+0.189$ (extraversion) $*+0.147$ (agreeableness) $*+0.156$ (conscientiousness) $*+-0.066$ (neuroticism) +0.077 (extraversion) $*+0.147$ (agreeableness) $*+0.156$ (conscientiousness) $*+-0.066$ (neuroticism) +0.077 (extra) openness) +0.126 (concrete support) +-0.077 (emotional support) +-0.75 (award support) +0.17 (suggestion support) $+\mathrm{e}$. From the regression equation, it can be seen that there are three variables whose regression coefficient values are significant: extraversion, agreeableness and consistency. 


\subsection{Proportion of Variants}

Table 8. The Contribution of Each Independent Variables Variant

\begin{tabular}{cccccccc}
\hline & & \multicolumn{7}{c}{ Change Statistics } \\
\cline { 5 - 8 } Model & $\mathrm{R}$ & R Square & & \multicolumn{7}{c}{$\begin{array}{c}\text { R Square } \\
\text { Change }\end{array}$} & F Change & df1 & df2 & Sig F Change \\
\cline { 5 - 8 } 1 & $.315^{\mathrm{a}}$ & .100 & .100 & 22.985 & 1 & 208 & .000 \\
2 & $.378^{\mathrm{b}}$ & .143 & .043 & 10.458 & 1 & 207 & .001 \\
3 & $.416^{\mathrm{c}}$ & .173 & .030 & 7.534 & 1 & 206 & .007 \\
4 & $.420^{\mathrm{d}}$ & .177 & .004 & .872 & 1 & 205 & .351 \\
5 & $.427^{\mathrm{e}}$ & .183 & .006 & 1.485 & 1 & 204 & .224 \\
6 & $.436^{\mathrm{f}}$ & .190 & .007 & 1.867 & 1 & 203 & .173 \\
7 & $.437 \mathrm{~g}$ & .191 & .001 & .201 & 1 & 202 & .654 \\
8 & $.439^{\mathrm{h}}$ & .193 & .002 & .444 & 1 & 201 & .506 \\
9 & $.439^{\mathrm{i}}$ & .193 & .000 & .027 & 1 & 200 & .870 \\
\hline
\end{tabular}

Based on data on Table 8, it can be seen that:

a) The extraversion variable contributes $10 \%$ to the variance of intuitive career decision making.

b) The agreeableness variable contributed $4.3 \%$ to the variance of intuitive career decision making.

c) Conscientiousness variable contributes 3\% to the variance of intuitive career decision making.

d) The neuroticism variable contributes $0.4 \%$ to the variance of intuitive career decision making.

e) The openness variable contributes $0.6 \%$ to the intuitive career decision making variance.

f) The variable concrete support contributes $0.7 \%$ to the variance of intuitive career decision making.

g) The variable emotional support contributes $0.1 \%$ to the variance of intuitive career decision making.

h) The award support variable contributes $0.2 \%$ to the intuitive career decision variance.

i) The advice support variable contributes $0 \%$ to the variance of intuitive career decision making.

\subsection{Results of the Dependent Career Decision Making Hypothesis Regression Analysis of Dependent Career Decision Making}

Table 9. R Square

\begin{tabular}{cccccc}
\hline Model & R & R Square & Adjusted R Square & Std. Error of the Estimate & Sig. F Change \\
\hline 1 & $.210^{\mathrm{a}}$ & .044 & .001 & 9.27016 & .000 \\
\hline
\end{tabular}

Based on Table 9, it can be seen that the R-Square is 0.044 or $4.4 \%$. That is, the proportion of variants to the dependent career decision variable is explained by the big five personality type variables (extraversion, agreeableness, conscientiousness, neuroticism, opennes) and family support (concrete support, emotional support, appreciation support, and suggestion support) in this study by $4,4 \%$, while the remaining $95.6 \%$ is influenced by other variables outside this study. 


\subsection{Anova Influence of Independent Variables on Dependent Career Decision Making}

\begin{tabular}{clccccc}
\multicolumn{7}{c}{$\begin{array}{c}\text { Table 10. Anova } \\
\text { ANOVA }\end{array}$} \\
\hline & Model & Sum of Squares & Df & Mean Square & F & Sig. \\
\hline \multirow{2}{*}{1} & Regression & 749.571 & 9 & 88.286 & 1.027 & $.419^{\mathrm{b}}$ \\
& Residual & 17187.177 & 200 & 85.936 & & \\
& Total & 17981.789 & 209 & & & \\
\hline
\end{tabular}

Based on the $\mathrm{F}$ test results in Table 10, it can be seen that the $\mathrm{P}$ value (Sig.) In the rightmost column is $p=0.419$ with a value of $p>0.05$. While it is known that the requirements for fulfilling the Sig. is $<0.05$, then the null hypothesis which states that "there is no significant effect of the big five personality types (extraversion, agreeableness, conscientiousness, neuroticism, openness) and family support (concrete support, emotional support, appreciation support, and suggestion support) on dependent career decision making behavior", accepted. The opposite means "there is no significant effect of the big five personality types (extraversion, agreeableness, conscientiousness, neuroticism, openness) and family support (concrete support, emotional support, appreciation support, and advice support) on dependent career decision making". The magnitude of the regression coefficients of each independent variable on rational career decision making can be seen in Table 11.

Table 11. Regression Coefficient

\begin{tabular}{ccc}
\hline Model & B & Sig \\
\hline Extraversion & .029 & .734 \\
Agreeeableness & -.177 & .029 \\
Conscientiousness & .073 & .406 \\
Neuroticism & -.044 & .960 \\
Openness & .119 & .170 \\
Concrete Support & -.049 & .621 \\
Emotional Support & .119 & .267 \\
Award Support & -.028 & .830 \\
Suggestion Support & .003 & .983 \\
\hline
\end{tabular}

Coefficients Based on the regression coefficients in Table 11, the regression equation is as follows: $(*$ significant) dependent career decision making $=45,763+0.029$ (extraversion) + 0.177 (agreeableness) +0.070 (conscientiousness) +-0.044 (neuroticism) +0.118 (openness) +0.045 (concrete support) +0.120 (emotional support) +-0.026 (award support) +0.003 (suggestion support) $+\mathrm{e}$. From the regression equation, it can be seen that there is one variable whose significance coefficient of regression is agreeableness. 


\subsection{Proportion of Variants}

Table 12. The Contribution of Each Independent Variables Variant

\begin{tabular}{|c|c|c|c|c|c|c|c|}
\hline \multirow[b]{2}{*}{ Model } & \multirow[b]{2}{*}{$\mathrm{R}$} & \multirow[b]{2}{*}{ R Square } & \multicolumn{5}{|c|}{ Change Statistics } \\
\hline & & & $\begin{array}{l}\text { R Square } \\
\text { Change }\end{array}$ & F Change & df1 & $\mathrm{df} 2$ & Sig F Change \\
\hline 1 & $.002^{\mathrm{a}}$ & -.033 & .002 & .383 & 1 & 208 & .536 \\
\hline 2 & $.013^{\mathrm{b}}$ & .004 & .012 & 2.445 & 1 & 207 & .119 \\
\hline 3 & $.026^{\mathrm{c}}$ & .011 & .012 & 2.541 & 1 & 206 & .112 \\
\hline 4 & $.036^{\mathrm{d}}$ & .007 & .000 & .064 & 1 & 205 & .800 \\
\hline 5 & $.036^{\mathrm{e}}$ & .012 & .010 & 2.168 & 1 & 204 & .142 \\
\hline 6 & $.036^{\mathrm{f}}$ & .008 & .000 & .006 & 1 & 203 & .941 \\
\hline 7 & $.044 \mathrm{~g}$ & .011 & .008 & 1.658 & 1 & 202 & .199 \\
\hline 8 & $.044^{\mathrm{h}}$ & .006 & .000 & .052 & 1 & 201 & .819 \\
\hline 9 & $.044^{\mathrm{i}}$ & .001 & .000 & .000 & 1 & 200 & .983 \\
\hline
\end{tabular}

Based on the data in Table 12, it can be seen that:

a) The extraversion variable contributes $0.2 \%$ to the dependent career decision variance.

b) The agreeableness variable contributed $1.2 \%$ to the dependent career decision making variance.

c) Conscientiousness variable contributed $1.2 \%$ to the dependent career decision variance.

d) The neuroticism variable contributes $0 \%$ to the dependent career decision variance.

e) The openness variable contributes $1 \%$ to the variance of dependent career decision making.

f) Concrete support variables contribute $0 \%$ to the dependent career decision variance.

g) The emotional support variable contributed $0.8 \%$ to the dependent career decision variance.

h) The award support variable contributes $0 \%$ to the dependent career decision variance.

i) The advice support variable contributes $0 \%$ to the dependent career decision making variance.

Variables of this study, the big five personality types variable influences rational career decision making, is in line with research Fabio, Palazzeschi and Baron (2012) which shows that personality influences career decision making, although different theories but supports research on the students of MAN 2 Cianjur.Rational approach also helps someone in planning their career goals, there is a rational planning and evaluation of what can be done in order to achieve the desired career decision (Khan, Riaz, Batool and Riaz, 2016). Big five personality type is a variable that does not stand alone. This variable has several dimensions that measure different abilities. In this study, it was found that not all dimensions of the big five personality types had a significant effect on rational career decision making.

Based on the value of the regression coefficient, extraversion. conscientiousness, and openness have a positive and significant influence on rational career decision making on students of MAN 2 Cianjur. This means that the higher the extraversion, conscientiousness, and openness, the higher the rational career decision-making ability of student as anindividual. This is in line with researchof Pejak and Kosir (2007) who found that personality influences career decision making. The results of his research found that individuals who score high on extraversion, conscientiousness, openness and emotional stability will be more competent in making a decision. 
The author assumes that rational career decision making is influenced by extraversion, because of students of MAN 2 Cianjur has a cheerful personality, likes to talk, likes to gather, and is more open about themself. So as to increase student knowledge about careers and students become more confident about themselves. This is inline with research Chen and $\mathrm{Su}$ Ann Liew (2015) which states that adolescents in Malaysia will easily make a decision if the teenager has a high extraversion value, although different theories but the results support research in MAN 2 Cianjur.

Then conscientiousness has an influence on rational career decision making, because of students of MAN 2 Cianjur has a personality that is characterized by regularity, controlled, organized, ambitious, focused on achievement and has self-discipline. So that the individual can make some logical considerations and careful planning before making a decision regarding his career. This is inline with researchof Jeffe and cott (Kummerow, 1991) which argues that conscientiousness has a high positive on the regression coefficient, it can be interpreted that the higher the value of conscientiousness, the higher the ability to determine career decision making. Decisions made are objective, logical and close to the truth. Harren (1979) revealed that rational career decision making can increase career maturity in individuals because it uses systematic and rational ways of making decisions.

Then openness has a significant influence on rational career decision making, because of students of MAN 2 Cianjur who has a personality that is characterized by an imaginative, creative, innovative personality, open-mindedness and high curiosity. So students can think more broadly and look for more information about their careers before the individual makes decisions about his career.

While agreeableness does not have a significant influence on rational career decision making. The author assumes that students of MAN 2 Cianjur with agreeableness personality types characterized by trustworthy personalities, the loser has not been able to make some logical judgment and careful planning before making a decision about his career.

Personality neuroticism does not have a significant influence on rational career decision making. The author assumes that students of MAN 2 Cianjur with neuroticism personality type which is characterized by personality such as full of anxiety, tempramental can not make some logical and realistic considerations, so it cannot make careful planning before making decisions about his career.

The results of subsequent studies found that the Big Five personality type has a significant and positive influence on intuitive career decision making. Big five personality types that have positive and significant influence are extraversion, agreeableness, and conscientiousness variables. This means that the higher the extraversion, agreeableness, and conscientiousness, the higher one's intuitive decision making ability.

In this research, extraversion that influences intuitive career decision making, which means someone who has a cheerful personality, likes to talk, and has fun can make decisions quickly based on his feelings or emotions, so someone who has a good extraversion personality type, will be able to encourage self-actualization in Intuitive career decision making.Then agreeableness has an influence on intuitive career decision making. Researchers assume, because students of MAN 2 Cianjur have a personality characterized by easily believing and easily accepting things. So that individual requires a short time in making a decision regarding his career, with several other considerations that are not considered.Then conscientiousness has an influence on intuitive career decision making, because the students of MAN 2 Cianjur have a personality characterized by ambitiously focused on achieving and having selfdiscipline. So that individuals can make decisions about his career well even with only a short time. 
Whereas the other two big five personality types have insignificant influence on intuitive career decision making namely neuroticism. The author assumes that students of MAN 2 Cianjur who have anxiety, emotional, and susceptible personalities to stress-related disorders have not been able to make a decision about their careers in a short time. Openness also does not have a significant influence on intuitive career decision making. The author assumes that students of MAN 2 Cianjur who have curious personalities and high curiosity also have not been able to make a decision about his career quickly and affect his career decision making.

The big five personality type has no significant effect on dependent career decision making. Researchers assume that MAN 2 Cianjur students can make their own decisions regarding their careers. Because those who have dependent career decision types usually tend to be influenced by others and have a maturity level in slow decisions, so they tend to easily lose their sense of fulfillment or personal satisfaction (Park \& Yang. 2014). Next is the family support variable, family support is divided into four namely concrete support, emotional support, appreciation support and advice support. Career decision making process is broadly influenced by one of them is finding information about careers from family and self experience, because the family is closer to daily life (Johnson, 1994).

The results of research at MAN 2 Cianjur is that there is no significant effect of family support on rational career decision making, intuitive career decision making, and dependent career decision making. This is in line with research Istifaran (2016) which states that there is no significant influence of family support on career decision making. This can be caused because there are several factors in students such as students becoming more independent in determining their own career choices without regard to the opinions of parents and other family members, the search for information relating to the career being undertaken at this time is a form of student independence.

In rational decision making, researchers assume that MAN 2 Cianjur students feel they have not received support from their families, both from real support, emotional support, appreciation support and support advice. The plans and preparations that have been prepared for his career have not received support from his family, while many things can be obtained if the initial plans for that career are fully supported by the family. In making rational career decisions individuals can make good plans, there is support from those closest to each decision taken, and an increase in self capacity that requires additional costs can also be obtained by these students.

Furthermore, there is no significant effect of family support on intuitive career decision making, which means MAN 2 Cianjur students have not received real support, emotional support, appreciation support, and support advice. Whereas if an individual gets support in the form of empathy, there is a need for and support given in the form of advice or input from family members can influence someone in making career decisions. Individuals tend to be more confident, committed to work, have good feelings about their future careers and can have certainty in making decisions (Xing, 2016). Especially the type of intuitive career decision making based on emotions or feelings.

The latest research results are that there is no significant effect of family support on dependent career decision making. The author assumes that MAN 2 Cianjur students tend not to be open to the family, who due to their low parental education background may be seen as lacking understanding of college matters, the profession of people who are predominantly farmers and traders is also considered to be less relevant to talk about the industrial world. Someone with dependent career decision making tends to depend on others, but may be due to the independence of MAN 2 Cianjur students, or because of the lack of closeness between individuals and their families and more likely teenagers closer to their peers or teachers at 
school. The author also assumes with his family background as a farmer or farm laborer that the child does not have family support.

\section{Conclusion}

The conclusions were obtained in this study. First, there is a significant influence of extraversion, conscientiousness, and openness on rational career decision making in the students of MAN 2 Cianjur. The most influential variable on rational career decision making is conscientiousness. Second, there is a significant influence of extraversion, agreeableness, conscientiousness towards intuitive career decision making in the students of MAN 2 Cianjur. The variable that has the biggest influence on intuitive career decision making is extraversion. Third is that there is no significant influence of the big five personality types (extraversion, agreeableness, conscientiousness, neuroticism, openness) and family support (concrete support, emotional support, appreciation support, and suggestion support) on dependent career decision making in the students of MAN 2 Cianjur.

\section{References}

[1] Costa, P.T. Jr., \& McCrae, R.R. (1995). Domains and facets: hierarchical personality assessment using the revised NEO personality inventory. Journal of Personality Assessment, 64 (1), 21-50. doi:10.1207/s15327752jpa6401_2.

[2] Dolan, P., Canavan, J., \& Pinkerton, J. (2006). Family support as a reflective practice. London: Jessica Kingsley.

[3] Fabio, A. D., Palazzeschi, L., Asulin-Peretz, L., \& Gati, I. (2012). Career indecision versus indecisiveness: associations with personality traits and emotional intelligence. Journal of Career Assessment. 21 (1), 42-56. doi: 10.1177/1069072712454698

[4] Fabio, A. D., Palazzeschi, L., \& Bar-On, R. (2012). The role of personality traits, core selfevaluation, and emotional intelligence in career decision-making difficulties. Journal of Employment Counseling.(49),118-129.

[5] Fadilla, F., Sinring, A., \& Aryani, F. (2015). Pengembangan model e-career untuk meningkatkan keputusan karir siswa SMA negeri 3 makassar. Jurnal Psikologi Pendidikan \& Konseling. 1 (2), 170-179.

[6] Guralnick, M. J. (2006). Family influences on early development: Integrating the science of normative development, risk \& disability and intervention. Oxford, UK: Blackwell Publishers.

[7] Harren, A.V. (1976). Tiedeman's approach to career development. Career Development Review, 25 (7), 895-916.

[8] Harren, A.V. (1979). A model of career decision making for college students. Journal of Vocational Behavior, 14, 119-133. doi: 10.1037/0022-0167.37.2.160

[9] Istifarani, F. (2016). Pengaruh dukungan keluarga terhadap pengambilan keputusan karir siswa kelas x di SMK negeri 1 Depok. E-Journal Bimbingan dan Konseling.4 (5), 1-11.

[10] Istifarani, F. (2016). Pengaruh dukungan keluarga terhadap pengambilan keputusan karir siswa kelas x di SMK negeri 1 Depok. E-Journal Bimbingan dan Konseling. 4 (5), 1-11.

[11] Johnson, S. B. (1994). Decision style and information gathering adolescent decision making styles and "fact finding".Paper Presented at the 1994 Australian Association for Research in Education.

[12] Kaur, H., Kaur, H., \& Venkateashan, M. (2015). Factors determining family support and quality of life of elderly population. International Journal of Medical Science and Public Health. 4(8), doi: 1049-1053. 10.5455/ijmsph.2015.21012015220 
[13] Khan, E. A., Riaz, M. N., Batool, N., \& Riaz, M. A. (2016). Emotional intelligence as a predictor of decision making styles among university students. Journal of Applied Environmental and Biological Sciences. 6 (4), 93-99.

[14] Kummerow, J. M. (1991). New direction in career planning. Palo Arto. California: CPP Book.

[15] Lee, Kibeom and Ashton, Michael C., (1966), The H Factor of Personality: Why Some People are Manipulative, Self-Entittled, Materialistic and Exploitative and Why It Matters for Everyone. Canada: Wilfrid Laurier University Press

[16] Mau, W. C. (2000). Cultural differences in career decision-making styles and self-efficacy. Journal of vocational behavior, 57 (3), 365-378. doi:10.1006/jvbe.1999.1745

[17] Mertens, Donna M dan Mclaughlin, John A., (2004), Research and Evaluation Methods in Special Education. California: Corwin Press, Inc.

[18] Park, M. H., \& Yang, K. S. (2014). The relationship between career decision-making styles and job seeking self-efficacy of college students in korea. Journal of Asian Vocational Education and Training, 32-39.

[19] Pecjak, Kosir. (2007). Personality motivation factors and difficulties in career decision making in secondary school students. Journal of psihologijske teme, 16(1), 141-158.

[20] Pervin, L. A., \& Cervone, D. (2011). Kepribadian: Teori dan Penelitian. Jakarta: Salemba Humanika.

[21] Pervin, L. A., Cervone, D., \& John, O. P. (2010). Psikologi Kepribadian: Teori \& Penelitian. Jakarta: Kencana.

[22] Santrock, J. W. (2011). Masa perkembangan anak. Jakarta: Salemba Humanika.

[23] Widyastuti, R. J., \& Pratiwi, T. I. (2013). Pengaruh self efficacy dan dukungan sosial keluarga terhadap kemantapan pengambilan keputusan karir siswa. Jurnal BK Unesa. 3(1), 231 - 238.

[24] Xing, X. (2016). Family influences on career decision making self-efficacy of secondary vocational students in china. A Dissertation submitted to the Graduate Faculty of The University of Georgia in Partial Fulfillment of the Requirements for the Degree. 